\title{
Effects of insulin-like growth factor I on the rates of glucose transport and utilization in rat skeletal muscle in vitro
}

\author{
George DIMITRIADIS, ${ }^{\circledR}$ Mark PARRY-BILLINGS,* Samantha BEVAN,* David DUNGER, $†$ Terence PIVA,* \\ Ulrike KRAUSE $\ddagger$ Gerhard WEGENER $\ddagger$ and Eric A. NEWSHOLME* \\ Department of * Biochemistry, and † Pediatrics, University of Oxford, South Parks Road, Oxford OX1 3QU, U.K., \\ and $\ddagger$ Institut für Zoologie, Johannes Gutenberg Universität, D-6500 Mainz, Germany
}

\begin{abstract}
1. The effects of insulin-like growth factor I (IGF-I) on the rates of glucose transport and utilization and its interaction with insulin were investigated in rat soleus muscle in vitro. IGF-I increased the rates of glucose transport, lactate formation, glycogen synthesis and the flux of glucose to hexose monophosphate, but it had no effect on the rate of glucose oxidation or glycogenolysis. 2. In the absence of insulin, low levels of IGF-I $(0-30 \mathrm{ng} / \mathrm{ml})$ increased the rate of glycolysis and the content of fructose 2,6-bisphosphate, but the content of glucose 6-phosphate remained unaltered; at higher levels of IGF-I (300-3000 ng/ml) the rate of glycolysis and the content of fructose 2,6-bisphosphate showed a further modest increase, but the content of glucose 6-phosphate doubled. Similar changes were seen when the level of insulin was increased from basal $(0-0.4 \mathrm{ng} / \mathrm{ml})$ to maximal $(40 \mathrm{ng} / \mathrm{ml})$. 3. Neither IGF-I nor insulin affected the contents of ATP, ADP, AMP, phosphocreatine or citrate. 4. Maximal concentrations of IGF-I increased the rate of lactate formation to a greater extent than did maximal concentrations of insulin. 5. In the presence of IGF-I, the rate of glucose utilization was less responsive to insulin. 6 . The results suggest that, in rat skeletal muscle: $(a)$ IGF-I increases the rates of glucose transport and utilization independently of insulin, and has a preferential effect on the rate of lactate formation; $(b)$ the effects of IGF-I and insulin are not additive; $(c)$ in addition to its effects on glucose transport, IGF-I increases the rate of glycogen synthesis and may stimulate glycolysis at the level of 6-phosphofructokinase; $(d)$ changes in the content of fructose 2,6-bisphosphate may be part of the mechanism to regulate glycolytic flux in skeletal muscle in response to either IGF-I or insulin.
\end{abstract}

\section{INTRODUCTION}

Insulin-like growth factor I (IGF-I) is one of the putative mediators of the growth-promoting effects of growth hormone [1]. IGF-I has a structural similarity to insulin [2], and its metabolic effects are considered to be similar to those of insulin [3]. Incubation of human or rat adipocytes with IGF-I increases the rates of glucose transport and glucose oxidation and inhibits that of lipolysis [4-7]. Incubation of mouse soleus muscle, human muscle or rat diaphragm in vitro with IGF-I increases the rates of glucose phosphorylation [8,9], glycolysis and glycogen synthesis $[3,8,10]$, and intravenous administration of IGF-I lowers the blood glucose concentration in rats [3,11] and in man [12]. However, in contrast with insulin, IGF-I is ineffective in suppressing hepatic glucose production, so that its hypoglycaemic effect after administration in vivo is presumably caused by an increase in the rate of glucose uptake in peripheral tissues $[11,13,14]$. Although skeletal muscle is considered to be the most important tissue for disposal of glucose [15], there is little information on the effects of IGF-I and its interaction with insulin on glucose uptake and utilization in this tissue. This study was undertaken to examine the effects of IGF-I on the rates of glucose transport and glucose utilization in the isolated stripped soleus muscle incubated both in the absence and in the presence of various concentrations of insulin.

\section{MATERIALS AND METHODS}

Male Wistar rats of $140 \mathrm{~g}$ body wt. were used (Olac, Bicester, Oxon, U.K.). Rats were fasted for $12 \mathrm{~h}$ before each experiment, and they were killed by cervical dislocation. All chemicals, biochemicals, enzymes and radiolabelled substances were obtained from sources given previously $[16,17]$.

\section{Muscle incubations}

Soleus muscle strips were prepared as previously described $[16,18]$. The isolated muscles were transferred into siliconetreated $25 \mathrm{ml}$ Erlenmeyer flasks with $3.5 \mathrm{ml}$ of Krebs-Ringer bicarbonate buffer containing $1 \mathrm{mM}$-pyruvate, -succinate and -Lglutamate and $5.5 \mathrm{~mm}$-D-glucose. Defatted BSA was added to a final concentration of $1.5 \%(\mathrm{w} / \mathrm{v})$ and the $\mathrm{pH}$ was adjusted to 7.30. The medium was gassed with $\mathrm{O}_{2} / \mathrm{CO}_{2}$ (19:1) during preparation and during the incubation, which was carried out at $37^{\circ} \mathrm{C}$. After $30 \mathrm{~min}$, the muscles were transferred into other flasks containing $3.5 \mathrm{ml}$ of identical Krebs-Ringer bicarbonate buffer except that pyruvate, succinate and L-glutamate were omitted but insulin was added $(0-40 \mathrm{ng} / \mathrm{ml})$. In each experiment, additional flasks which contained an identical amount of incubation buffer but no muscles were included as controls. After 60 min incubation, the muscles were quickly removed, blotted and freeze-clamped in liquid $\mathrm{N}_{2}$, and the frozen muscles were processed for determination of metabolites. The size of the muscle strips used in the experiments was $32 \pm 0.27 \mathrm{mg}$.

In the experiments where the effects of IGF-I were studied, IGF-I was added to the incubation medium at a final concentration of $25-30 \mathrm{ng} / \mathrm{ml}(3-3.6 \mathrm{nM})$. In the experiments in which the rate of 3-O-methylglucose transport was measured, IGF-I was also added to the preincubation medium at the same final concentration.

\section{Glycolysis, glycogen synthesis and glucose oxidation}

For experiments in which the rates of glycogen synthesis and 
Table 1. Effects of various concentrations of IGF-I on the rates of 3-O-methyl| ${ }^{3} \mathrm{H} \mid g l u c o s e$ transport, flux of glucose to hexose monophosphate, glycogen synthesis, lactate formation, $\left[{ }^{14} \mathrm{C} \mid\right.$ lactate formation, glucose oxidation and the contents of glucose 6-phosphate and fructose 2,6-bisphosphate in the stripped soleus muscle of the rat

Results are presented as means \pm S.E.M. of 5-8 separate incubations. Statistical significance was tested, and differences from values at previous concentrations of IGF-I are indicated by ${ }^{\mathrm{a}} P<0.02,{ }^{\mathrm{b}} P<0.01$ and ${ }^{\mathrm{c}} P<0.001$; differences between the rates of lactate formation and $\left[{ }^{14} \mathrm{C}\right]$ lactate formation are indicated by $\dagger P<0.02$ and $\dagger \dagger P<0.001$.

\begin{tabular}{|c|c|c|c|c|c|}
\hline & \multicolumn{5}{|c|}{ [IGF-I] (ng/ml) } \\
\hline & 0 & 3 & 30 & 300 & 3000 \\
\hline \multicolumn{6}{|l|}{ Rates $(\mu \mathrm{mol} / \mathrm{h}$ per $\mathrm{g})$} \\
\hline 3-O-Methyl $\left[{ }^{3} \mathrm{H}\right]$ glucose transport & $4.39 \pm 0.08$ & $4.86 \pm 0.39$ & $6.12 \pm 0.27^{\mathrm{a}}$ & $6.80 \pm 0.13^{\mathrm{a}}$ & $7.14 \pm 0.21$ \\
\hline Flux of glucose to hexose monophosphate & $4.87 \pm 0.33$ & $5.55 \pm 0.27$ & $8.19 \pm 0.56^{\mathrm{c}}$ & $11.63 \pm 0.49^{c}$ & $13.44 \pm 0.70$ \\
\hline Glycogen synthesis & $2.19 \pm 0.20$ & $2.25 \pm 0.14$ & $3.63 \pm 0.29^{c}$ & $5.64 \pm 0.45^{\mathrm{c}}$ & $6.98 \pm 0.45$ \\
\hline Glucose oxidation & $0.23 \pm 0.04$ & $0.24 \pm 0.04$ & $0.23 \pm 0.03$ & $0.29 \pm 0.06$ & $0.37 \pm 0.06$ \\
\hline \multicolumn{6}{|l|}{ Content } \\
\hline Glucose 6-phosphate $(\mu \mathrm{mol} / \mathrm{g})$ & $0.086 \pm 0.003$ & $0.084 \pm 0.008$ & $0.105 \pm 0.007$ & $0.205 \pm 0.009^{c}$ & $0.208 \pm 0.006$ \\
\hline Fructose 2,6-bisphosphate $(\mathrm{nmol} / \mathrm{g})$ & $0.338 \pm 0.030$ & $0.446 \pm 0.030^{2}$ & $0.544 \pm 0.030^{2}$ & $0.752 \pm 0.056^{b}$ & $0.673 \pm 0.050$ \\
\hline
\end{tabular}

glucose oxidation were measured, $\left[\mathrm{U}-{ }^{14} \mathrm{C}\right]$ glucose was added to the incubation medium at a final specific radioactivity of $0.4 \mu \mathrm{Ci} / \mathrm{ml}$. The rate of incorporation of ${ }^{14} \mathrm{C}$ into glycogen was measured as described previously [19]. For measurement of the rate of glucose oxidation, at the end of the incubation and after the muscles were removed, the flasks were rapidly re-sealed and the incubation medium was acidified with $\mathrm{HClO}_{4}$ (final concn. $4 \%, w / v)$. The flasks were left on ice for $60 \mathrm{~min}$. The ${ }^{14} \mathrm{CO}_{2}$ was trapped in pieces of filter paper moistened with $200 \mu \mathrm{l}$ of 2-phenylalanine/methanol $(1: 1, \mathrm{v} / \mathrm{v})$; the radioactivity was measured in a scintillation counter [20]. The rate of glycolysis was estimated from the rate of lactate formation.

Rates of glucose transport and phosphorylation, flux of glucose to hexose monophosphate and contents of 2-deoxyglucose and metabolites

The rate of glucose phosphorylation was measured by monitoring the accumulation of 2-deoxy $\left[{ }^{3} \mathrm{H}\right]$ glucose 6-phosphate in muscles after incubation with 2-deoxy $\left[{ }^{3} \mathrm{H}\right]$ glucose $[17,21]$. In addition, the intracellular level of 2-deoxy $\left[{ }^{3} \mathrm{H}\right]$ glucose was measured after separation from 2-deoxy $\left[{ }^{3} \mathrm{H}\right]$ glucose 6-phosphate and measurement of the extracellular volume by using $\left[{ }^{14} \mathrm{C}\right]$ sucrose. Trace amounts of 2-deoxy $\left[{ }^{3} \mathrm{H}\right]$ glucose and $\left[\mathrm{U}-{ }^{14} \mathrm{C}\right]$ sucrose were added to the incubation medium: the final specific radioactivities were $0.5 \mu \mathrm{Ci} / \mathrm{ml}$ and $0.1 \mu \mathrm{Ci} / \mathrm{ml}$ for 2deoxyglucose and sucrose respectively. The frozen muscles were powdered in liquid $\mathrm{N}_{2}$, homogenized in $6 \% \mathrm{HClO}_{4}$ and centrifuged to remove precipitated protein. The supernatant $(1 \mathrm{ml})$ was neutralized and placed on a $1.5 \mathrm{ml}$ Dowex-2 (formate form) ionexchange column. The columns were washed first with $10 \mathrm{ml}$ of distilled water containing $5 \mathrm{~mm}-\mathrm{D}$-glucose to elute $\left[{ }^{14} \mathrm{C}\right]$ sucrose and 2-deoxy $\left[{ }^{3} \mathrm{H}\right]$ glucose and then with $10 \mathrm{ml}$ of $0.3 \mathrm{M}$ ammonium formate/ $1 \mathrm{M}$-formic acid to elute 2-deoxy $\left[{ }^{3} \mathrm{H}\right]$ glucose 6-phosphate. Preliminary experiments showed that both washes were sufficient to elute all radioactivity from columns. The radioactivity in $1 \mathrm{ml}$ of each eluate was measured in a liquidscintillation counter.

The flux from glucose to hexose monophosphate (representing the sum of the rates of glucosyl units going into glycogen and through the glycolytic pathway) was also calculated as a sum of the rates of $\left[{ }^{14} \mathrm{C}\right]$ lactate formation and glycogen synthesis. $\left[{ }^{14} \mathrm{C}\right]$ Lactate was separated from other labelled compounds in the incubation medium by ion-exchange chromatography [22]; the radioactivity found in the incubation medium of control flasks was subtracted from each value of $\left[{ }^{14} \mathrm{C}\right]$ lactate.

The rate of glucose transport was measured by using 3-Omethyl $\left[{ }^{3} \mathrm{H}\right]$ glucose, a glucose analogue which is transported but not further metabolized [23]. Muscles were incubated in KrebsRinger bicarbonate buffer identical with that described above, except that D-glucose was omitted. After 30 min preincubation, the muscles were further incubated for $10 \mathrm{~min}$ in buffer containing 3-O-methylglucose $(5.5 \mathrm{~mm}), 3-O$-methyl[ $\left.{ }^{3} \mathrm{H}\right]$ glucose and $\left[\mathrm{U}-{ }^{14} \mathrm{C}\right]$ sucrose (final specific radioactivities were $2 \mu \mathrm{Ci} / \mathrm{ml}$ and $0.1 \mu \mathrm{Ci} / \mathrm{ml}$ respectively) and insulin. After incubation, the muscles were removed, washed briefly in ice-cold Krebs-Ringer bicarbonate buffer, blotted dry and freeze-clamped in liquid $\mathrm{N}_{2}$. The frozen muscles were digested in $0.5 \mathrm{ml}$ of $1 \mathrm{M}-\mathrm{KOH}$ at $70^{\circ} \mathrm{C}$ for 20-30 min. The muscle digest was transferred into scintillation vials and the tubes were rinsed once with $0.5 \mathrm{ml}$ of distilled water. Scintillation fluid $(10 \mathrm{ml})$ was added to the vials, the mixture was acidified with $150 \mu \mathrm{l}$ of acetic acid and the radioactivity was measured in a liquid-scintillation counter.

The net uptake of 2-deoxy[ $\left[{ }^{3} \mathrm{H}\right]$ glucose and 3-O-methyl$\left[{ }^{3} \mathrm{H}\right]$ glucose into the muscles was calculated after correction for the ${ }^{3} \mathrm{H}$ radioactivity trapped in the extracellular space; the latter was measured by using $\left[{ }^{14} \mathrm{C}\right]$ sucrose. Preliminary experiments established that the rate of $3-O$-methyl $\left[{ }^{3} \mathrm{H}\right]$ glucose transport was linear for at least $20 \mathrm{~min}$ in the presence of 0.04 or $400 \mathrm{ng}$ of insulin $/ \mathrm{ml}$.

The contents of glucose 6-phosphate [24], fructose 1,6bisphosphate [25], fructose 2,6-bisphosphate [26,27], ATP [28], ADP [29], AMP [29], phosphocreatine [30] and citrate [31] were measured after extraction of the muscles with $6 \% \mathrm{HClO}_{4}$.

The significance of the difference between controls and experimental results was tested by non-paired Student's $t$ test.

\section{RESULTS}

\section{Effects of IGF-I on the rates of glucose transport and utilization and the contents of glucose 6-phosphate and fructose 2,6-bisphosphate}

IGF-I increased the rate of 3-O-methylglucose transport, the flux of glucose to hexose monophosphate (representing the rate of total glucose utilization in the muscle) and the rates of lactate formation and glycogen synthesis. IGF-I had no significant effect on the rate of glucose oxidation; in contrast, insulin increased 
Table 2. Effects of IGF-I (30 ng/ml) on the rates of 3-O-methyll ${ }^{3} \mathrm{H} \mid$ glucose transport, lactate formation, glycogen synthesis and flux of glucose to hexose monophosphate in the stripped soleus muscle of the rat at various concentrations of insulin

Results are presented as means \pm S.E.M. of at least six separate incubations. Statistical significance was tested, and differences from controls are indicated by ${ }^{\mathrm{a}} P<0.02,{ }^{\mathrm{b}} P<0.001$; differences from values at basal concentrations of insulin $(0-0.4 \mathrm{ng} / \mathrm{ml})$ are indicated by $\dagger P<0.02,{ }^{*} P<0.01$, ** $P<0.001$

\begin{tabular}{|c|c|c|c|c|c|c|}
\hline Rates $(\mu \mathrm{mol} / \mathrm{h}$ per $\mathrm{g})$ & & \multicolumn{5}{|c|}{ [Insulin] (ng/ml) } \\
\hline Flux of glucose to hexose monophosphate & $\begin{array}{l}\text { Control } \\
\text { IGF-I }\end{array}$ & $\begin{array}{l}4.02 \pm 0.34 \\
7.81 \pm 0.55^{b}\end{array}$ & $\begin{array}{l}4.09 \pm 0.29 \\
8.12 \pm 0.56^{b}\end{array}$ & $\begin{array}{l}4.12 \pm 0.30 \\
7.18 \pm 0.38^{b}\end{array}$ & $\begin{array}{l}7.09 \pm 0.66^{* *} \\
9.09 \pm 0.59^{2 *}\end{array}$ & $\begin{array}{c}10.13 \pm 0.80^{* *} \\
9.79 \pm 0.50 \dagger\end{array}$ \\
\hline Lactate formation & $\begin{array}{l}\text { Control } \\
\text { IGF-I }\end{array}$ & $\begin{array}{c}8.56 \pm 0.53 \\
13.69 \pm 0.83^{b}\end{array}$ & $\begin{array}{c}8.79 \pm 0.54 \\
14.11 \pm 0.82^{\mathrm{b}}\end{array}$ & $\begin{array}{c}9.08 \pm 0.34 \\
12.48 \pm 0.48^{b}\end{array}$ & $\begin{array}{l}11.79 \pm 0.69^{* *} \\
14.79 \pm 0.50^{\mathrm{b}}\end{array}$ & $\begin{array}{l}13.48 \pm 0.63^{* *} \\
14.22 \pm 0.92\end{array}$ \\
\hline
\end{tabular}

Table 3. Effects of IGF-I $(30 \mathrm{ng} / \mathrm{ml})$ on the rate of phosphorylation and content of 2-deoxy $\left.\right|^{3} \mathrm{H} \mid$ glucose in the stripped soleus muscle of the rat at various concentrations of insulin

Results are presented as means \pm S.E.M. of at least six separate incubations. Statistical significance was tested, and differences from controls are indicated by ${ }^{\mathrm{a}} P<0.02,{ }^{\mathrm{b}} P<0.001$; differences from basal concentrations of insulin $(0-0.4 \mathrm{ng} / \mathrm{ml})$ are indicated by ${ }^{*} P<0.01$ and ${ }^{* *} P<0.001$.

\begin{tabular}{|c|c|c|c|c|}
\hline \multirow{2}{*}{$\begin{array}{l}\text { Insulin } \\
(\mathrm{ng} / \mathrm{ml})\end{array}$} & \multicolumn{2}{|c|}{$\begin{array}{l}\text { Rate of 2-deoxy }\left[{ }^{3} \mathrm{H}\right] \text { glucose phosphorylation } \\
\qquad(\mu \mathrm{mol} / \mathrm{h} \text { per } \mathrm{g})\end{array}$} & \multicolumn{2}{|c|}{$\begin{array}{c}\text { Content of 2-deoxy }\left[{ }^{3} \mathrm{H}\right] \text { glucose in muscle } \\
(\mu \mathrm{mol} / \mathrm{g})\end{array}$} \\
\hline & Control & IGF-I & Control & IGF-I \\
\hline 0 & $4.00 \pm 0.19$ & $6.68 \pm 0.30^{\mathrm{b}}$ & $0.392 \pm 0.03$ & $0.694 \pm 0.04^{b}$ \\
\hline 0.04 & $3.93+0.22$ & $6.76+0.16^{b}$ & $0.360+0.03$ & $0.677+0.04^{b}$ \\
\hline 0.4 & $4.37 \pm 0.30$ & $6.53 \pm 0.37^{b}$ & $0.396 \pm 0.04$ & $0.630 \pm 0.09^{a}$ \\
\hline 4 & $7.13 \pm 0.23^{* *}$ & $8.03+0.36^{* \mathrm{a}}$ & $0.586+0.02^{* *}$ & $0.670+0.02$ \\
\hline 40 & $9.78 \pm 0.56$ & $9.18 \pm 0.39 * *$ & $0.818 \pm 0.03^{* *}$ & $0.779 \pm 0.07$ \\
\hline
\end{tabular}

this rate by more than 2 -fold when the concentration was increased from $0.4 \mathrm{ng} / \mathrm{ml}(0.150 \pm 0.02 \mu \mathrm{mol} / \mathrm{h}$ per $\mathrm{g})$ to $40 \mathrm{ng} / \mathrm{ml}$ $(0.395 \pm 0.02 \mu \mathrm{mol} / \mathrm{h}$ per $\mathrm{g} ; P<0.001)$ (Table 1$)$.

The concentrations of IGF-I required to stimulate the rate of lactate formation and the rate of glycogen synthesis halfmaximally $\left(\mathrm{EC}_{50}\right)$ (3.00 and $11.76 \mathrm{nM}$ respectively; Table 1$)$ were higher than those of insulin (0.419 and $1.15 \mathrm{nM}$ respectively, calculated from results presented in Table 2).

The rates of total lactate formation and $\left[{ }^{14} \mathrm{C}\right]$ lactate formation increased similarly in response to IGF-I, but the basal rate of total lactate formation was higher than that of $\left[{ }^{14} \mathrm{C}\right]$ lactate formation. This difference was presumably caused by glycogenolysis and was similar in the absence $(2.53 \pm 0.5 \mu \mathrm{mol} / \mathrm{h}$ per g) or presence of IGF-I $(3.00 \pm 0.38 \mu \mathrm{mol} / \mathrm{h}$ per $\mathrm{g}$ at $3000 \mathrm{ng} / \mathrm{ml})$. This suggests that IGF-I, at the concentrations used, has no effect on the rate of glycogenolysis.

The rates of glucose transport and glucose utilization were similar at basal concentrations of IGF-I and insulin. However, maximal concentrations of IGF-I increased the flux of glucose to hexose monophosphate and the rates of 3-O-methylglucose transport and lactate formation to a greater extent than did the maximal concentrations of insulin $(P<0.02)$, whereas the effects on the rate of glycogen synthesis were not significantly different (Tables 1 and 2).

When the level of IGF-I was increased to $30 \mathrm{ng} / \mathrm{ml}$, the rate of glucose transport, the flux of glucose to hexose monophosphate, the flux to glycogen and the glycolytic flux were increased; however, there was no significant increase in the content of glucose 6-phosphate, whereas that of fructose 2,6-bisphosphate increased by $60 \%$. A further increase in the concentration of IGF-I to 300 or $3000 \mathrm{ng} / \mathrm{ml}$ further increased the rate of glucose transport, the flux of glucose to hexose monophosphate, the flux to glycogen and the glycolytic flux; in this case the content of glucose 6-phosphate doubled, but the content of fructose 2,6bisphosphate increased by less than $40 \%$ (Table 1).

Similarly, when the concentration of insulin was increased to $4 \mathrm{ng} / \mathrm{ml}$, the rate of glucose transport, the flux to glycogen and the glycolytic flux were increased; however, the content of glucose 6-phosphate remained unaltered, but the content of fructose 2,6-bisphosphate increased by $40 \%$. An increase in the concentration of insulin to $40 \mathrm{ng} / \mathrm{ml}$ further increased the rate of glucose transport, the flux of glucose to glycogen and the glycolytic flux; in this case the content of glucose 6-phosphate increased by $150 \%$, whereas that of fructose 2,6-bisphosphate increased only slightly (16\%) (Tables 2 and 4$)$

Calculation of the contribution of glycolysis and glycogen synthesis to glucose utilization showed that at $0 \mathrm{ng}$ of IGF-I/ml the contribution to glycolysis was higher than that of glycogen synthesis $(56 \pm 1.7 \%$ and $44 \pm 1.7 \%$ respectively; $P<0.001)$; at $3000 \mathrm{ng}$ of IGF-I $/ \mathrm{ml}$ the contributions of glycolysis and glycogen synthesis were similar ( $48 \pm 2 \%$ and $52 \pm 2 \%$ respectively).

Rates of glucose transport and utilization and contents of metabolites in muscle in response to IGF-I and insulin

IGF-I at $25-30 \mathrm{ng} / \mathrm{ml}$ were used in these experiments to approximate to the physiological levels found in the plasma of fasting man [12]. At this concentration, IGF-I markedly increased the rates of lactate formation and glycogen synthesis and the flux 
Table 4. Effects of IGF-I (30 ng/ml) on the contents of glucose 6-phosphate, fructose 1,6-bisphosphate and fructose 2,6-bisphosphate in rat soleus muscle at various concentrations of insulin

Results are presented as means \pm S.E.M. of at least four separate incubations. Statistical analysis was tested, and differences between controls and IGF-I are indicated by ${ }^{\mathrm{a}} P<0.05,{ }^{\mathrm{b}} P<0.02,{ }^{\mathrm{c}} P<0.01$ and ${ }^{\mathrm{d}} P<0.001$; differences from basal concentrations of insulin $(0.04-0.4 \mathrm{ng} / \mathrm{ml})$ are indicated by ${ }^{*} P<0.05,{ }^{* *} P<0.01$; differences from values at $4 \mathrm{ng}$ of insulin $/ \mathrm{ml}$ are indicated by $\dagger P<0.001$.

\begin{tabular}{|c|c|c|c|c|c|c|}
\hline \multirow{2}{*}{$\begin{array}{l}\text { Insulin } \\
(\mathrm{ng} / \mathrm{ml})\end{array}$} & \multicolumn{2}{|c|}{$\begin{array}{l}\text { Glucose 6-phosphate } \\
(\mu \mathrm{mol} / \mathrm{g})\end{array}$} & \multicolumn{2}{|c|}{$\begin{array}{c}\text { Fructose 1,6-bisphosphate } \\
(\mu \mathrm{mol} / \mathrm{g})\end{array}$} & \multicolumn{2}{|c|}{$\begin{array}{l}\text { Fructose 2,6-bisphosphate } \\
\text { (nmol/g) }\end{array}$} \\
\hline & Control & IGF-I & Control & IGF-I & Control & IGF-I \\
\hline 0.04 & $0.216 \pm 0.049$ & $0.068 \pm 0.030^{2}$ & $0.046 \pm 0.007$ & $0.072 \pm 0.003^{b}$ & - & - \\
\hline 0.4 & $0.195 \pm 0.029$ & $0.100 \pm 0.004^{c}$ & $0.030 \pm 0.004$ & $0.066 \pm 0.014^{b}$ & $0.380 \pm 0.041$ & $0.545 \pm 0.060^{\mathrm{a}}$ \\
\hline 4 & $0.266 \pm 0.026$ & $0.164 \pm 0.045^{\mathrm{a}}$ & $0.038 \pm 0.009$ & $0.076 \pm 0.010^{\mathrm{b}}$ & $0.532 \pm 0.025^{* *}$ & $0.752 \pm 0.077^{b}$ \\
\hline 40 & $0.407 \pm 0.025^{* *} \dagger$ & $0.139 \pm 0.034^{\mathrm{d}}$ & $0.032 \pm 0.008$ & $0.053 \pm 0.006^{\mathrm{b} *}$ & $0.619 \pm 0.050^{* *}$ & $0.795 \pm 0.140$ \\
\hline
\end{tabular}

Table 5. Effects of IGF-I (30 ng/ml) on the contents of ATP, ADP, AMP, phosphocreatine and citrate in rat soleus muscle at various concentrations of insulin

Results are presented as means \pm S.E.M. of five separate incubations.

\begin{tabular}{|c|c|c|c|c|c|c|c|c|c|c|}
\hline \multirow{2}{*}{$\begin{array}{l}\text { Insulin } \\
(\mathrm{ng} / \mathrm{ml})\end{array}$} & \multicolumn{2}{|c|}{$\underset{(\mu \mathrm{mol} / \mathrm{g})}{\operatorname{ATP}}$} & \multicolumn{2}{|c|}{$\underset{(\mu \mathrm{mol} / \mathrm{g})}{\operatorname{ADP}}$} & \multicolumn{2}{|c|}{$\underset{(\mu \mathrm{mol} / \mathrm{g})}{\operatorname{AMP}}$} & \multicolumn{2}{|c|}{$\begin{array}{l}\text { Phosphocreatine } \\
(\mu \mathrm{mol} / \mathrm{g})\end{array}$} & \multicolumn{2}{|c|}{$\begin{array}{c}\text { Citrate } \\
(\mathrm{nmol} / \mathrm{g})\end{array}$} \\
\hline & Control & IGF-I & Control & IGF-I & Control & IGF-I & Control & IGF-I & Control & IGF-I \\
\hline $\begin{array}{l}0 \\
0.4 \\
4 \\
40\end{array}$ & $\begin{array}{l}4.63 \pm 0.22 \\
4.34 \pm 0.25 \\
4.79 \pm 0.40 \\
4.48 \pm 0.21\end{array}$ & $\begin{array}{l}4.93 \pm 0.35 \\
4.03 \pm 0.15 \\
4.41 \pm 0.29 \\
4.03 \pm 0.04\end{array}$ & $\begin{array}{l}0.905 \pm 0.06 \\
0.903 \pm 0.06 \\
0.952 \pm 0.05 \\
1.007 \pm 0.07\end{array}$ & $\begin{array}{l}1.001 \pm 0.09 \\
0.988 \pm 0.04 \\
0.891 \pm 0.08 \\
0.873 \pm 0.07\end{array}$ & $\begin{array}{l}0.092 \pm 0.018 \\
0.093 \pm 0.004 \\
0.091 \pm 0.005 \\
0.091 \pm 0.009\end{array}$ & $\begin{array}{l}0.100 \pm 0.041 \\
0.111 \pm 0.005 \\
0.101 \pm 0.007 \\
0.084 \pm 0.009\end{array}$ & $\begin{array}{l}5.35 \pm 0.38 \\
4.31 \pm 0.32 \\
5.08 \pm 0.88 \\
4.79 \pm 0.33\end{array}$ & $\begin{array}{l}5.70 \pm 0.51 \\
4.24 \pm 0.29 \\
4.55 \pm 0.61 \\
4.26 \pm 0.41\end{array}$ & $\begin{array}{l}71 \pm 16 \\
77 \pm 11 \\
80 \pm 18 \\
88 \pm 7\end{array}$ & $\begin{array}{r}90 \pm 14 \\
100 \pm 15 \\
75 \pm 18 \\
89 \pm 14\end{array}$ \\
\hline
\end{tabular}

of glucose to hexose monophosphate at $0-4 \mathrm{ng}$ of insulin $/ \mathrm{ml}$, but not at $40 \mathrm{ng}$ of insulin $/ \mathrm{ml}$. However, the flux of glucose to hexose monophosphate and the rate of glycogen synthesis did not reach their maximal values: these rates were further increased as insulin increased from 0 to $4 \mathrm{ng} / \mathrm{ml}$. In contrast, the rate of lactate formation did not increase further, even when insulin was added at maximal concentrations (Table 2).

IGF-I increased the rates of 3-O-methylglucose transport and 2-deoxyglucose phosphorylation at $0-4 \mathrm{ng}$ of insulin $/ \mathrm{ml}$, but not at $40 \mathrm{ng}$ of insulin $/ \mathrm{ml}$. The rate of 3-O-methylglucose transport was increased maximally by IGF-I (Table 2), whereas the rate of 2-deoxyglucose phosphorylation was further increased with increasing concentrations of insulin (Table 3).

The content of 2-deoxyglucose increased as the level of insulin increased from basal to maximal. IGF-I increased the content of 2-deoxyglucose at $0-0.4 \mathrm{ng}$ of insulin/ $\mathrm{ml}$, and in the presence of IGF-I increasing concentrations of insulin did not affect the content of 2-deoxyglucose (Table 3). IGF-I decreased the content of glucose 6-phosphate and increased that of fructose 1,6bisphosphate; also, IGF-I increased the content of fructose 2,6bisphosphate at 0.4 and $4 \mathrm{ng}$ of insulin/ml (Table 4). In the presence of IGF-I, the content of fructose 1,6-bisphosphate at $0 \mathrm{ng}$ of insulin $/ \mathrm{ml}$ was higher than that observed at $40 \mathrm{ng}$ of insulin $/ \mathrm{ml}$ (Table 4).

IGF-I, either alone or in combination with insulin, had no effect on the contents of ATP, ADP, AMP, phosphocreatine or citrate (Table 5).

\section{DISCUSSION}

The results suggest that IGF-I can stimulate the rate of glucose utilization in muscle independently of insulin. Furthermore, IGF-I can increase the rate of conversion of glucose into lactate. To identify the mechanism(s) by which IGF-I stimulates glucose utilization, the rates of glucose transport, glycolysis and glycogen synthesis and the contents of some glycolytic intermediates and effectors were measured in the incubated muscle.

The IGF-I dose-response experiments presented in Table 1 suggest that the increase in the rate of glycolysis is caused, in part, by a stimulation of glucose transport. The finding that the increase in the rate of 3-O-methylglucose transport caused by a sub-maximal, near-physiological, concentration of IGF-I $(30 \mathrm{ng} / \mathrm{ml})$ was similar to that produced by a maximal concentration of insulin suggests that IGF-I results in a redistribution of glucose transporters from the intracellular pool to the plasma membrane. This mechanism has been established for insulin in skeletal muscle [32,33]. This suggestion is supported by the finding that IGF-I did not have an additive effect with insulin on the rate of 3-O-methylglucose transport. However, the observation that a maximal concentration of IGF-I increased the rate of 3-O-methylglucose transport to a greater extent than did a maximal concentration of insulin suggests that IGF-I either also increased the activity of those transporters already in the membrane or caused a net increase in translocation of other transporters (e.g. glut-I) to the plasma membrane. The physiological importance of the effect of IGF-I on glucose transport is that it may be the main mechanism by which IGF-I produces a hypoglycaemic effect in vivo, since it does not affect hepatic glucose production, nor does it decrease the rate of fatty acid mobilization from adipose tissue $[11,13,14]$.

The increase in the rate of glucose transport may not be the only mechanism by which IGF-I increases the rate of glycolysis and lactate formation, but this peptide may have additional effects that facilitate the glycolytic process. The changes in the content of glucose 6-phosphate suggest that IGF-I may increase the activity of 6-phosphofructokinase by a mechanism independent of fructose 6-phosphate. Thus, when IGF-I was increased from 0 to $30 \mathrm{ng} / \mathrm{ml}$, the flux through this enzyme was increased (since the rate of glycolysis was increased), yet the content of glucose 6-phosphate, and presumably that of fructose 
6-phosphate, with which it is in equilibrium, remained unaltered; this suggests that IGF-I must have enhanced the activity of a reaction further down the glycolytic pathway, which is likely to be 6-phosphofructokinase. The increase in the rate of glycolysis caused by IGF-I (in combination with the increase in the rate of glycogen synthesis) may, when insulin is also present, decrease the content of glucose 6-phosphate; the latter effect would be expected to increase the activity of hexokinase, since glucose 6phosphate is a potent inhibitor of hexokinase [32]; this could contribute to the increase in the rate of glucose phosphorylation. These results support the suggestion that IGF-I, by increasing the activity of 6-phosphofructokinase, and hence that of hexokinase, should facilitate the increase in the glycolytic rate caused by the increase in the rate of glucose transport.

IGF-I increased the rate of glycogen synthesis. In mouse soleus muscle, IGF-I has been reported to increase the activity of glycogen synthase [8]. However, the stimulation of glucose transport cannot explain the effect of IGF-I on glycogen synthesis: the enzyme glycogen synthase is considered to catalyse a flux-generating step, so that it will not be influenced by a change in the concentration of its substrate, UDP-glucose. Furthermore, IGF-I decreased the concentration of glucose 6-phosphate, a known activator of this enzyme [32].

In the present study, a maximally effective insulin concentration increased the rate of glucose utilization; this effect was smaller than that observed in vivo when infusions of labelled glucose are used [34]. However, in vivo, these effects of insulin could be facilitated by some indirect effects of this hormone, such as decreasing the plasma level of alternative fuels (fatty acids, ketone bodies) which are known to influence the activity of 6phosphofructokinase and hence hexokinase [32]. The soleusmuscle preparation provides an isolated system in which the effects of insulin can be studied with minimal influence by other factors.

The mechanism by which IGF-I increases the activity of 6phosphofructokinase could be via stimulation by fructose 2,6bisphosphate, since in the presence of IGF-I the content of fructose 2,6-bisphosphate was increased, whereas the contents of other effectors of this enzyme were not affected. Fructose 2,6bisphosphate is a potent activator of 6-phosphofructokinase, but its role in the regulation of glucose utilization in skeletal muscle has not been established. Since fructose 2,6-bisphosphate is neither a substrate nor an intermediate of glycolysis, it would be an apt mediator for extracellular signals such as hormones [27,35]. In the present experiments, the changes in the content of fructose 2,6-bisphosphate in muscle in response to IGF-I or insulin coincide with those observed in the glycolytic rate, but are opposite to the changes observed in the content of glucose 6phosphate. This suggests that, when IGF-I is increased within the range $0-30 \mathrm{ng} / \mathrm{ml}$, an increase in fructose 2,6-bisphosphate is part of the mechanism to increase the activity of 6phosphofructokinase and hence the glycolytic flux; this, along with a simultaneous direct effect of IGF-I to increase the rate of glycogen synthesis, would maintain the content of glucose 6phosphate unaltered, although the rate of glucose transport is increased. Similar suggestions can be made when the level of insulin is increased within the physiological range (Table 4). In contrast, the increase in glucose 6-phosphate at supraphysiological levels of insulin may be caused by a further increase in the rate of glucose transport not matched with a stimulation of 6-phosphofructokinase activity; in this case, the increase in 6phosphofructokinase and the stimulation of glycolysis could be caused solely by an increase in the content of intracellular glucose consequent upon stimulation of glucose transport; indeed, the content of 2-deoxyglucose in the soleus muscle was increased when insulin increased from physiological to maximal levels. At these supraphysiological concentrations of insulin, this would also help to direct glucose residues to glycogen rather than to lactate [34]. Similarly, when the level of IGF-I increased from 30 to $3000 \mathrm{ng} / \mathrm{ml}$, the content of glucose 6-phosphate doubled; this latter increase may be explained, at least in part, by the lower increases in the content of fructose 2,6-bisphosphate and the rate of glycolysis compared with those produced at concentrations of IGF-I below $30 \mathrm{ng} / \mathrm{ml}$. These results suggest that changes in the content of fructose 2,6-bisphosphate may play an important role in the regulation of glucose fluxes in skeletal muscle in response to either IGF-I or insulin. In a recent study in working frog muscle, changes in glycolytic flux were closely correlated with changes in the content of fructose 2,6-bisphosphate [27].

Near-physiological concentrations of IGF-I not only decreased the content of glucose 6-phosphate, but also increased that of fructose 1,6-bisphosphate: such a 'cross-over effect' is consistent with an increase in the activity of 6-phosphofructokinase. However, a comparison of the effects of IGF-I alone (at $30 \mathrm{ng} / \mathrm{ml}$ ) with insulin alone (at $40 \mathrm{ng} / \mathrm{ml}$ ) reveals that, despite a similar glycolytic flux and fructose 2,6-bisphosphate content, the content of fructose 1,6-bisphosphate was increased in the presence of IGF-I. This raises the possibility that insulin may result in an increase in the activity of one or more enzymes below 6phosphofructokinase (e.g. glyceraldehyde-phosphate dehydrogenase via small change in the redox state).

Despite the similarities between effects of IGF-I and insulin on glucose metabolism, the effects of IGF-I are considered to occur via the IGF-I receptor and not the insulin receptor [8,36-38]. This is further supported by the finding that IGF-I seems to have a preferential effect on the rate of glycolysis and lactate formation.

In summary, IGF-I increases the rate of glucose transport in the isolated soleus muscle, but also affects the subsequent disposition of glucose: it increases the rates of glycolysis and glycogen synthesis, but not the rate of glucose oxidation. The increase in the rate of glycolysis and lactate formation in muscle by IGF-I might be expected to increase the activity of Cori cycle to a greater extent than insulin, and therefore provide substrate for the 'indirect' pathway of hepatic glycogen synthesis.

We acknowledge financial support from British Diabetes Association and Medical Research Council. G.D. was a Wellcome Trust Fellow. G.W. was supported by a grant from the Deutsche Forschungsgemeinschaft, D-5300 Bonn, Germany. We thank Dr. Linda Fryklund and Kabi Pharmacia for support and generous provision of IGF-I.

\section{REFERENCES}

1. Schoenle, E., Zapf, J., Humbel, R. \& Froesch, R. (1982) Nature (London) 296, 252-253

2. Rinderknecht, E. \& Humbel, R. (1978) J. Biol. Chem. 253, 2769-2776

3. Zapf, J., Hauri, C., Waldvogel, M. \& Froesch, R. (1986) J. Clin. Invest. 77, 1768-1775

4. Bolinder, J., Lindblad, A., Engfeldt, P. \& Arner, P. (1987) J. Clin. Endocrinol. Metab. 65, 732-737

5. Kern, P., Svoboda, M., Eckel, R. \& Van Wyk, J. (1989) Diabetes 38, 710-717

6. Schoenle, E., Zapf, J., Froesch, R. (1977) Diabetologia 13, 243-249

7. Sinha, M., Buchanan, C., Leggett, N., Martin, L., Khazanie, P., Dimarchi, R., Pories, W. \& Caro, J. (1989) Diabetes 38, 1217-1225

8. Poggi, C., Le Marchand-Brustel, Y., Zapf, J., Froesch, R. \& Freychet, P. (1979) Endocrinology (Baltimore) 105, 723-730

9. Dohm, L., Elton, C., Radju, M., Mooney, N., Dimarchi, R., Pories, W., Flickinger, E., Atkinson, S. \& Caro, J. (1990) Diabetes 39, 1028-1032

10. Uthne, K., Reagan, C., Gimpel, L. \& Kostyo, J. (1974) J. Clin. Endocrinol. Metab. 39, 548-554

11. Jacob, R., Barrett, E., Plewe, G., Fagin, R. \& Sherwin, R. (1989) J. Clin. Invest. 83, 1717-1723 
12. Guler, H., Zapf, J. \& Froesch, R. (1987) N. Engl. J. Med. 317, $137-140$

13. Giacca, A., Gupta, R., Efendic, S., Hall, K., Skottner, A., Lickley, L. \& Vranic, M. (1990) Diabetes 39, 340-347

14. Jacob, R., Sherwin, R., Bowen, L., Fryburg, D., Fagin, K., Tamborlane, W. \& Shulman, G. (1991) Am. J. Physiol. 260, 262-268

15. De Fronzo, R., Jequier, J., Maeder, E. \& Felber, J. (1981) Diabetes 30, 1000-1007

16. Espinal, J., Dohm, L. \& Newsholme, E. A. (1983) Biochem. J. 212, 453-458

17. Dimitriadis, G., Leighton, B., Parry-Billings, M., West, D. \& Newsholme, E. A. (1988) Biochem. J. 257, 369-373

18. Crettaz, M., Prentki, M., Zaninetti, D. \& Jeanrenaud, B. (1980) Biochem. J. 186, 525-534

19. Guendet, G., Loten, E., Jeanrenaud, B. \& Renold, A. (1976) J. Clin. Invest. 58, 1078-1088

20. Leighton, B., Budohoski, L., Lozeman, F., Challiss, R. A. J. \& Newsholme, E. A. (1985) Biochem. J. 227, 337-340

21. Challiss, R. A. J., Arch, J. \& Newsholme, E. A. (1984) Biochem. J. 221, 153-161

22. Hammerstedt, R. (1980) Anal. Biochem. 109, 443-448

23. Young, D., Uhl, J., Cartee, G. \& Holloszy, J. (1986) J. Biol. Chem. 261, 16049-16053

24. Michal, G. (1984) in Methods of Enzymatic Analysis (Bergmeyer, H. U., ed.), pp. 191-198, Verlag Chemie, Weinheim
25. Michal, G. (1984) in Methods of Enzymatic Analysis (Bergmeyer, H. U., ed.), pp. 342-350, Verlag Chemie, Weinheim

26. Van Schaftingen, E. (1984) in Methods of Enzymatic Analysis (Bergmeyer, H. U., ed.), pp. 335-341, Verlag Chemie, Weinheim

27. Wegener, G., Krause, U. \& Thuy, M. (1990) FEBS Lett. 267, $257-260$

28. Jaworek, D. \& Welsch, J. (1984) in Methods of Enzymatic Analysis (Bergmeyer, H. U., ed.), pp. 340-346, Verlag Chemie, Weinheim

29. Jaworek, D. \& Welsch, J. (1984) in Methods of Enzymatic Analysis (Bergmeyer, H. U., ed.), pp. 365-370, Verlag Chemie, Weinheim

30. Passonneau, J. \& Brown, J. (1984) in Methods of Enzymatic Analysis (Bergmeyer, H. U., ed.), pp. 191-198, Verlag Chemie, Weinheim

31. Moellering, H. (1984) in Methods of Enzymatic Analysis (Bergmeyer, H. U., ed.), pp. 6-12, Verlag Chemie, Weinheim

32. Newsholme, E. A. \& Leech, A. (1983) Biochemistry for the Medical Sciences, J. Wiley, New York and London

33. Klip, A., Ramlal, T., Young, D. \& Holloszy, J. (1987) FEBS Lett. 224, 224-230

34. Rossetti, L. \& Giaccari, A. (1990) J. Clin. Invest. 85, 1785-1792

35. Hers, H. \& Van Schaftingen, E. (1982) Biochem. J. 206, 2-12

36. Meuli, C. \& Froesch, R. (1977) Biochem. Biophys. Res. Commun. 75, 689-695

37. Yu, K. \& Czech, M. (1984) J. Biol. Chem. 259, 3090-3095

38. Rossetti, L., Frontoni, S., Dimarchi, R., DeFronzo, R. \& Giaccari, A. (1991) Diabetes 40, 444-448

Received 6 January 1992; accepted 4 February 1992 